\title{
Phenotypic divergence in viviparid snails in a recently converted freshwater lagoon
}

\author{
Osamu Kagawa ${ }^{1, *}$, Takumi Saito $^{2}$, Shota Uchida ${ }^{1} \&$ Satoshi Chiba ${ }^{1,3}$ \\ ${ }^{1}$ Graduate School of Life Sciences, Tohoku University, 2-2-2 Katahira, Aoba, Sendai, Miyagi 980-8576, Japan \\ ${ }^{2}$ Department of Biology, Faculty of Science, Toho University, 2-2-1 Miyama, Funabashi, Chiba 274-8510, Japan \\ ${ }^{3}$ Center for Northeast Asian Studies, Tohoku University, 41 Kawauchi, Aoba, Sendai, Miyagi 980-8576, Japan
}

Received 13 March 2019; Accepted 13 June 2019 Responsible Editor: Osamu Miura

doi: $10.3800 /$ pbr. 14.189

\begin{abstract}
Freshwater mollusks often show high intraspecific variability in shell morphology, which may cause incongruences between molecular phylogeny and morphology-based species taxonomy. However, it remains unclear how morphological variations in freshwater snails are associated with different habitats such as rivers, ponds, and lakes. In the present study, we investigated the morphological variation in the shells of the viviparid freshwater snail Sinotaia quadrata in the Kahoku Lagoon in Japan, which was converted from a brackish to a freshwater lagoon 60 years ago. This newly established freshwater habitat is particularly well-suited for studies on how morphology is associated with environments. We found clear differences in shell morphologies between the $S$. quadrata populations sampled inside and outside of the lagoon. The S. quadrata sampled in the lagoon had thicker and more elongated shells with wider apertures than those sampled outside of the lagoon. No relationship was found between shell morphology and the distance between sampling sites. This suggests that the divergence in shell morphology occurred over a fairly short time period by rapid adaptation or phenotypic plasticity. Although it is unclear whether these differences are caused by phenotypic plasticity or adaptation, the present findings suggest that the shell morphologies of freshwater snails easily change under the influence of the environment. The high flexibility in shell morphology should be carefully considered when managing or studying freshwater mollusks.
\end{abstract}

Key words: freshwater mollusks, shell morphology, Sinotaia quadrata, Viviparidae

\section{Introduction}

How taxonomists identify and discriminate species affects the estimations of biodiversity and the development of ecosystem conservation programs (Mace 2004, Lenat \& Resh 2006, Garnett \& Christidis 2017). DNA-barcoding and environmental DNA techniques are increasingly used to determine species composition in communities; however, the taxonomy of most eukaryotes remains primarily based on morphological characteristics (Deiner et al. 2017). On the other hand, many species show incongruences between molecular phylogeny and morphology-based taxonomy (Patterson et al. 1993, Irestedt et al. 2004, Havermans et al. 2010, Covain et al. 2016, San et al. 2018). In particular, freshwater snails often show re-

*Corresponding author: Osamu Kagawa; E-mail, ok.osamukagawa@ gmail.com markable incongruences between molecular phylogeny and morphology-based taxonomy (Köhler \& Glaubrecht 2006, Pfenninger et al. 2006, Lee et al. 2007, Du et al. 2013, Hirano et al. 2015, Becker et al. 2016, Köhler 2016, Saito et al. 2018a). This sometimes results in problems when estimating species diversity for conservation programs for freshwater mollusks (Saito et al. 2018b). Potential causes of these incongruences include introgressive hybridization, ancient polymorphisms, the presence of cryptic species, rapid evolution, and highly plastic morphological traits (Glaubrecht \& Köhler 2004, Lee et al. 2007, Miura et al. 2013, Köhler 2016, Hirano et al. 2019). These phenomena have been suggested by phylogenetic studies; however, many of these studies have not clarified the mechanisms underlying these incongruences. In particular, environmental pressures influence the selection of genotypes that underlie the expression of suitable phenotypic traits (Preston \& Roberts 2007), as well as the expression of phe- 

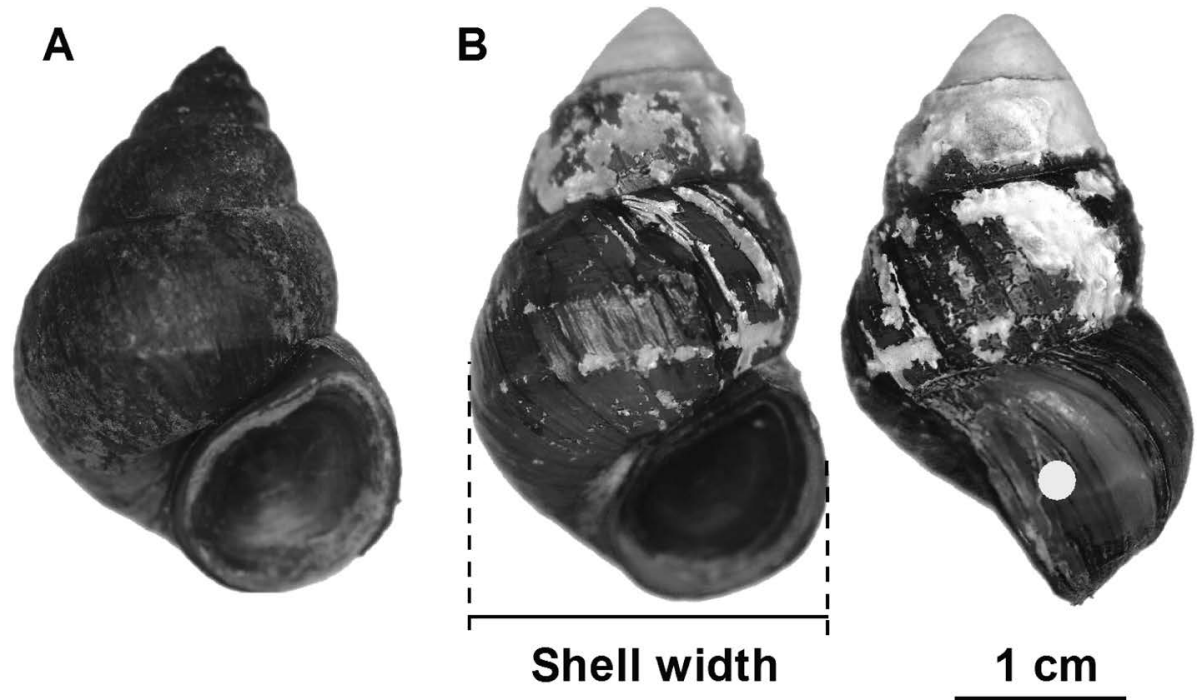

Fig. 1. Sinotia quadrata. 1A: a representative individual sampled outside of the Kahoku Lagoon. 1B: a representative individual sampled within the Kahoku Lagoon. The Position shown with a white point indicate where we measured shell thickness.

notypic plasticity, in which phenotypes change according to the environment (Hollander et al. 2006, Hoverman \& Relyea 2009, Dunithan et al. 2012, Cazenave \& Zanatta 2016). Nevertheless, the relationships between phenotype and environments of freshwater mollusks have not been fully considered in these phylogenetic studies.

To clarify the relationship between morphology and environment, we investigated morphological variations in Sinotaia quadrata (Fig. 1). S. quadrata is broadly distributed across East Asia, and occurs in various environmental habitats (e.g., rivers, water channels, rice fields, wetlands, and lakes) (Masuda \& Uchiyama 2004, Hirano et al. 2015). Based on fossil records, Japanese populations of $S$. quadrata were most likely introduced from the Asian continent around 4,000 years ago (Kurozumi 2013). Furthermore, a recent molecular phylogenetic study suggested that $S$. quadrata from the Asian continent and Japan could not be distinguished by two mitochondrial molecular markers (Hirano et al. 2015). In addition, this phylogeny also showed that $S$. quadrata found inside and outside of Lake Biwa in Shiga Prefecture, Japan, had quite different shell morphologies, but shared the same haplotype. However, the relationship between phenotype and environment has not been investigated quantitatively. Therefore, we focused on Kahoku Lagoon to test the morphological variation in S. quadrata between S. quadrata found inside and outside of the lagoon. Kahoku Lagoon was formed over 1,000 years ago and was originally brackish (Kahokugata Lake Institute 2013). However, this lagoon was converted to a freshwater lagoon as a result of a reclamation project that began in 1963 (Kawahara \& Takahashi 2001), and subsequently, because of the desalination of the lagoon, brackish organisms disappeared from Kahoku Lagoon, and were replaced by freshwater organisms (Kahokugata Lake Institute 2013). S. quadrata currently occur inside of the current Kahoku Lagoon and in water channels connected to the lagoon (Nomura \& Takahashi 2006). As such, the populations of $S$. quadrata within Kahoku Lagoon settled in this lagoon less than 60 years ago. This means that the desalinated Kahoku Lagoon can be considered a new habitat for S. quadrata, and therefore this lagoon provides an excellent opportunity to elucidate the relationship between phenotype and environment. Using this unique model system, we aimed to evaluate how the morphology of $S$. quadrata differs between $S$. quadrata that occur inside and outside of Kahoku Lagoon.

\section{Materials and Methods}

\section{Study sites and sampling}

The sampling of $S$. quadrata was conducted around Kahoku Lagoon, Kanazawa City, Japan (36 39'05.4"N, $\left.136^{\circ} 40^{\prime} 08.2^{\prime \prime} \mathrm{E}\right)$. The survey sites included six locations in Kahoku Lagoon ( $\mathrm{n}=54$ S. quadrata) and 13 locations in the surrounding area ( $\mathrm{n}=127$ S. quadrata) (Fig. 2 and Table 1). As the concentration of calcium ions in the water affects the shell morphology of freshwater mollusks (Marin et al. 1996, Rundle et al. 2004), the calcium ion concentrations were measured using an ion meter at each collection site (LAQUAtwin-Ca-11, accuracy $\pm 20 \%$, Horiba, Japan, note that a calcium ion data of sampling site 5 was missing value). Collected $S$. quadrata were brought back to the laboratory within one week, boiled at $100^{\circ} \mathrm{C}$ for 5 minutes, and stored in $99.5 \%$ ethanol.

\section{Quantification of shell morphology}

Elliptic Fourier analysis was used to describe and quantify shell morphology (Williams et al. 2012, Doyle et al. 2018, Jackson \& Claybourn 2018). Images of S. quadrata 
shells were acquired using a digital camera (K-S2, Ricoh, Japan), from which elliptic Fourier analysis was performed using SHAPE (Iwata \& Ukai 2006). Since shell size or shell thickness are not taken into account in elliptic Fourier analysis, shell width as shell size was measured from the image using Image J (Schneider et al. 2012), and shell thickness was measured using a point micrometer (CPM15,

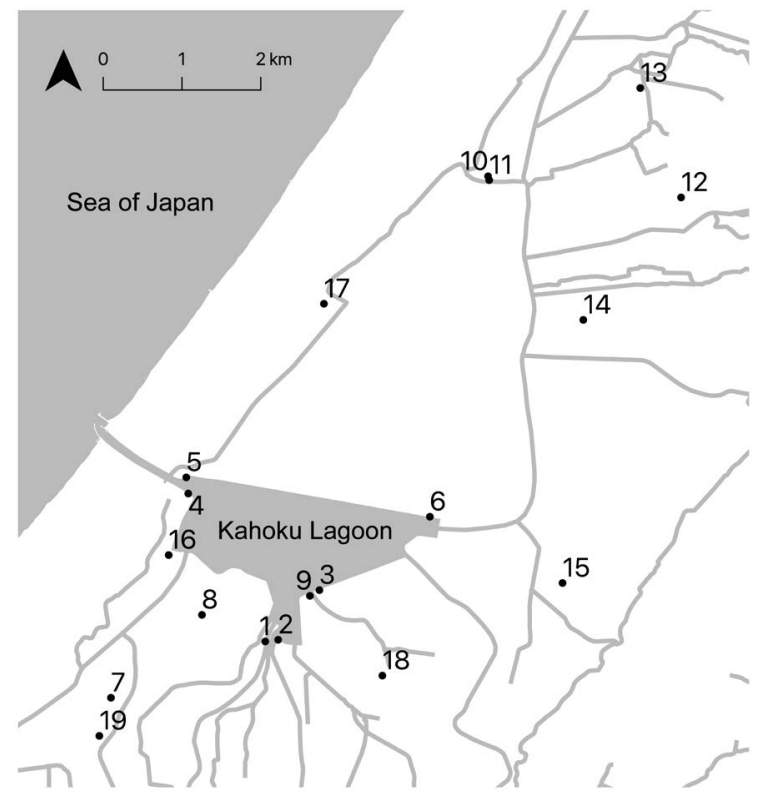

Fig. 2. Map of Kahoku Lagoon and the surrounding area. Points indicate the sampling sites included in this study. Sites numbered 1-6 are within Kahoku Lagoon, and sites numbered 7-19 are outside of Kahoku Lagoon. accuracy $\pm 0.001 \mathrm{~mm}$, Mitsutoyo, Japan) (Fig. 1B).

\section{Statistical analysis}

In order to investigate whether the outline of shells differ between $S$. quadrata sampled from inside and outside the lagoon, we constructed generalized linear mixed models (GLMMs) with Gaussian distributions. In the GLMMs, principal component scores (PC1 to PC5) obtained by elliptic Fourier analysis were included as dependent variables, and a model was constructed with each of the principal component scores. The information on whether the individual $S$. quadrata was collected from within the lagoon or from outside the lagoon was included as the fixed effect. The inside/outside of the lagoon status was converted to $0 / 1$ in the analyses. To account for differences in sampled locations, the sampling site was included as a random effect. The significance of the models was examined by comparing the full model and the null model using a likelihood ratio test with chi-square distributions.

In order to determine whether shell thickness and size of $S$. quadrata differ inside and outside the lake, we conducted analysis using the same method (GLMMs with Gaussian distributions). The shell thickness and size (shell width) were designated as a dependent variable in each model, and the habitat (inside and outside of the lagoon) was included as the fixed effect, with sampling site included as a random effect. In addition, since shell thickness is affected by shell size, in the model that included thickness as a dependent variable, shell size was added as a fixed effect.

Different calcium ion concentrations may cause differences in shell morphology, and therefore the difference in

Table 1. Descriptions of sampling sites, average shell sizes, and numbers of individual Sinotia quadrata sampled.

\begin{tabular}{|c|c|c|c|c|c|}
\hline Site number & Place & Environments & $\mathrm{Ca}^{2+}(\mathrm{mg} / \mathrm{L})$ & Mean of the shell size \pm s. e. $(\mathrm{mm})$ & $\mathrm{n}$ \\
\hline 1 & inside of the Lagoon & rock, sand, mad, emerging plants & 27 & $18.3 \pm 0.23$ & 12 \\
\hline 2 & inside of the Lagoon & mad, emerging plants & 48 & $22.5 \pm 1.31$ & 2 \\
\hline 3 & inside of the Lagoon & mad, rock, emerging plants & 25 & $18.3 \pm 0.24$ & 18 \\
\hline 4 & inside of the Lagoon & rock, mad & 23 & $16.6 \pm 0.33$ & 8 \\
\hline 5 & inside of the Lagoon & sand, mad, emerging plants & 26 & 15.4 & 1 \\
\hline 6 & inside of the Lagoon & rock, sand, mad, emerging plants & NA & $19.9 \pm 0.30$ & 13 \\
\hline 7 & rice field, water channel & $\operatorname{mad}$ & 27 & $16.9 \pm 0.50$ & 15 \\
\hline 8 & water channel & mad, wall of concrete & 52 & $17.3 \pm 0.24$ & 10 \\
\hline 9 & water channel & mad, wall of concrete & 53 & $20.4 \pm 0.43$ & 14 \\
\hline 10 & water channel & $\operatorname{mad}$ & 29 & $18.8 \pm 1.16$ & 3 \\
\hline 11 & river & rock, mad & 27 & $20.4 \pm 0.72$ & 4 \\
\hline 12 & water channel, rice field & $\operatorname{mad}$ & 28 & $20.2 \pm 0.94$ & 11 \\
\hline 13 & water channel, rice field & $\operatorname{mad}$ & 41 & $18.9 \pm 0.36$ & 14 \\
\hline 14 & water channel, rice field & $\operatorname{mad}$ & 26 & $15.4 \pm 0.35$ & 3 \\
\hline 15 & water channel, rice field & $\operatorname{mad}$ & 16 & $16.8 \pm 0.47$ & 5 \\
\hline 16 & water channel, rice field & sand, mad & 35 & $21.1 \pm 0.32$ & 19 \\
\hline 17 & water channel & $\operatorname{mad}$ & 12 & $19.9 \pm 0.40$ & 16 \\
\hline 18 & water channel, rice field & $\operatorname{mad}$ & 27 & $17.5 \pm 1.00$ & 6 \\
\hline 19 & water channel & mad, wall of concrete & 40 & $17.0 \pm 0.40$ & 7 \\
\hline
\end{tabular}


calcium ion concentrations between sampling sites inside and outside of the lagoon was examined using the MannWhitney U test.

The difference in shell morphology may be determined by the geographical distance between sampling sites, and not by differences in environmental pressures. Therefore, we conducted a Mantel test that examined the correlation between the matrices, in order to investigate whether the morphological differences between the sampling sites correlated with the geographical distances between the sampling locations. The values for morphological traits were included as principal component scores (PC1 to PC5) and morphological measurements (shell width and thickness), respectively.

All analyses were performed in R-3.4.1. (R Development Core Team 2005). GLMMs were performed using package Lme4 (Bates et al. 2019). Mann-Whitney U tests were performed using package exactRankTests (Hothorn \& Hornik 2019). Mantel tests were performed using package vegan (Oksanen et al. 2019).

\section{Results}

Results of the principal component analysis of the elliptic Fourier analysis showed that at least $83 \%$ of the variation in $S$. quadrata shell morphology was explained by the first five principal components (PC1: 54.9\%; PC2: 10.5\%; PC3: 9.26\%; PC4: 4.83\%; PC5: 4.03\%). The outline from each principal component was reconstructed using the results of the elliptic Fourier analysis (Fig. 3). GLMMs, which tested whether PC scores were different inside and outside the lagoon, showed that the values for PC2 and PC3 differed significantly between sampling sites located inside and outside of the lagoon, respectively (PC2: $P=0.002$; PC3: $P=0.047$, Table 2, Fig. 4). These principal component scores were lower for the shells of $S$. quadrata sampled inside than those sampled outside of the lagoon (Table 2, Fig. 4). However, the other principal components were not significantly different between sampling sites located inside and outside of the lagoon ( $\mathrm{PC} 1: P=0.857$; PC4: $P=0.423$; PC5: $P=0.616$ ) (Table 2).
After measuring the shells, we found that the average shell size of $S$. quadrata sampled from sites inside the lagoon was $18.54 \pm 0.22 \mathrm{~mm}$ (mean \pm s.e.) and the average shell size of $S$. quadrata sampled outside the lake was $18.97 \pm 0.21 \mathrm{~mm}$ (mean \pm s.e.) $\mathrm{mm}$. The shell size was not significantly different between $S$. quadrata sampled from sites located inside and outside the lagoon $(P=0.979$, Table 2). Shell thickness showed a significant positive correlation with shell size ( $P=0.001$, Fig. 5 , Table 2$)$. Additionally, the shells tended to be thicker in $S$. quadrata sampled within the lagoon than $S$. quadrata sampled outside the lagoon, although the difference was not statistically significant ( $P=0.052$, Fig. 5, Table 2). Calcium ion concentrations did not differ between sites located inside and outside of the lagoon $(P=0.320)$ (Table 1), and, therefore, calcium ion concentration was not related to the morphological variations in S. quadrata shells.

There was no correlation between $S$. quadrata shell morphology and geographical distance between sampling sites (Table 3).

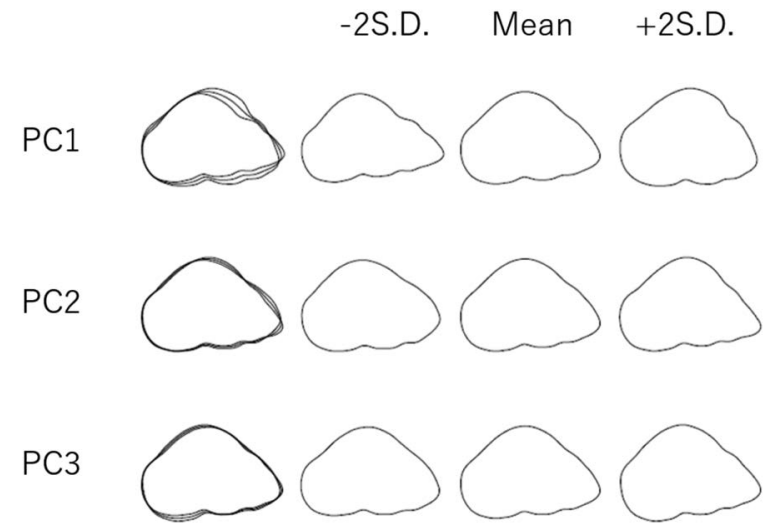

Fig. 3. Contour illustrations reconstructed by elliptic Fourier analysis of Sinotia quadrata shells. The outlines represent the mean of the shape, plus and minus two standard deviations (S.D.) for each principal component. The first row is an overlap of the three.

Table 2. The results of generalized linear mixed models (GLMMs) used in this study. In order to investigate whether the shell morphologies differ between $S$. quadrata sampled from inside and outside the lagoon, we constructed GLMMs with Gaussian distributions.

\begin{tabular}{|c|c|c|c|c|c|c|c|c|c|c|}
\hline \multirow{2}{*}{ Shell morphology } & \multicolumn{2}{|c|}{ Intercept } & \multicolumn{4}{|c|}{ Place } & \multicolumn{4}{|c|}{ Shell size } \\
\hline & Estimate & S. E. & Estimate & S. E. & $X^{2}$ & $P$ value & Estimate & S. E. & $X^{2}$ & $P$ value \\
\hline PC1 & -0.0017 & 0.0099 & 0.0022 & 0.012 & 0.033 & 0.86 & - & - & - & - \\
\hline PC2 & -0.013 & 0.0038 & 0.016 & 0.0045 & 9.6 & 0.0020 & - & - & - & - \\
\hline PC3 & -0.0051 & 0.0031 & 0.0074 & 0.0037 & 3.9 & 0.047 & - & - & - & - \\
\hline PC4 & 0.00087 & 0.0019 & -0.0017 & 0.0023 & 0.63 & 0.86 & - & - & - & - \\
\hline PC5 & 0.00082 & 0.0020 & -0.0011 & 0.0024 & 0.25 & 0.42 & - & - & - & - \\
\hline Shell size & 18.57 & 0.80 & -0.027 & 0.95 & 0.00070 & 0.98 & - & - & - & - \\
\hline Shell thickness & -0.14 & 0.090 & -0.073 & 0.038 & 3.8 & 0.052 & 0.031 & 0.0046 & 41 & 0.0013 \\
\hline
\end{tabular}



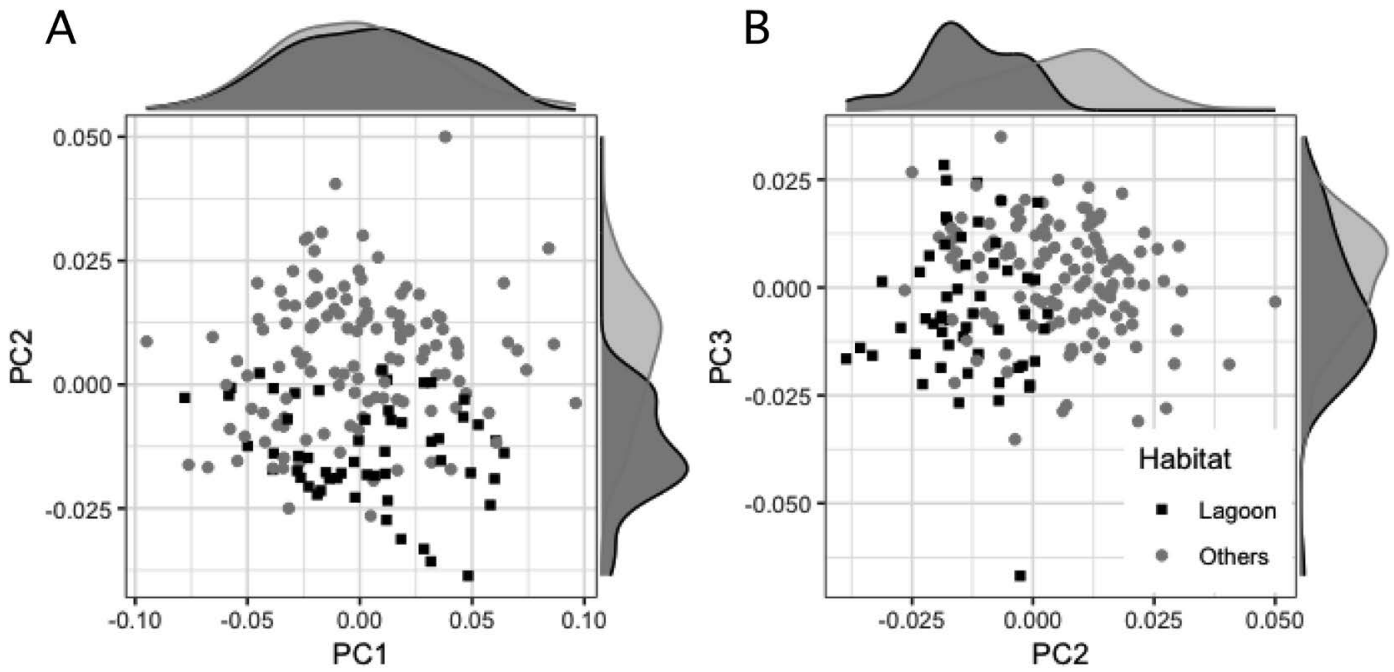

Fig. 4. Plots of the top three principal components obtained by elliptic Fourier analysis of Sinotia quadrata shells. Distributions on the upper and right sides of the plots show the density of the points. Fig. 4A indicates the relationship between PC1 and PC2. Fig. 4B indicates the relationship between PC2 and PC3. Black square symbols indicate S. quadrata collected from inside of Kahoku Lagoon. Grey circle symbols indicate $S$. quadrata collected from locations outside of Kahoku Lagoon, including rice fields, rivers, and water channels.

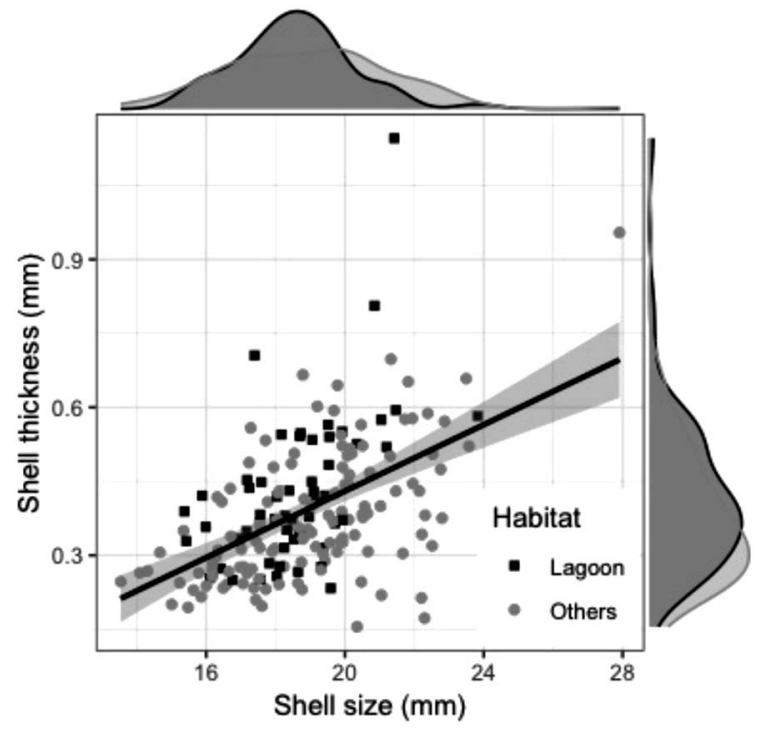

Fig. 5. Plot indicating the relationship between shell size and shell thickness. The line is the regression line between shell size and shell thickness, and the grey range along the line indicates the 95\% confidence interval. Distributions on the upper and right sides of the plots show the density of the points. Black square symbols indicate $S$. quadrata collected from inside of Kahoku Lagoon. Grey circle symbols indicate $S$. quadrata collected from locations outside of Kahoku Lagoon, including rice fields, rivers, and water channels.

\section{Discussion}

The results of the elliptic Fourier analysis showed that PC2 and PC3 of $S$. quadrata were significantly different between sites located inside and outside of the lagoon (Table 2). Lower values for PC2 indicate a more elongated, cylindrical shape, while higher values for PC2 reflect a
Table 3. The results of Mantel tests used to analyze whether the morphological differences in Sinotia quadrata shells between the sampling sites correlated with the geographical distances between the sampling locations.

\begin{tabular}{lrc}
\hline Shell morphology & \multicolumn{1}{c}{$\mathrm{R}$} & P value \\
\hline PC1 & 0.046 & 0.073 \\
PC2 & -0.059 & 0.985 \\
PC3 & 0.028 & 0.176 \\
PC4 & -0.023 & 0.734 \\
PC5 & 0.032 & 0.173 \\
Shell size & 0.394 & 0.122 \\
Shell thickness & 0.039 & 0.134 \\
\hline
\end{tabular}

more conical shape (Figs. 3, 4). PC3 represents differences in the bulge of the outer edge of the shell's aperture; higher values indicate wider apertures (Figs. 3, 4). Therefore, because these PC scores reflect the expansion rate of shell aperture size with growth, the $S$. quadrata inside the lagoon have elongated cylindrical shells, while the $S$. quadrata outside the lagoon have conical shells. Shell size did not differ between the sites located inside and outside of the lagoon (Table 2), suggesting that the lagoon environment has no effect on $S$. quadrata shell size. On the other hand, regarding shell thickness, the $S$. quadrata sampled inside of the lagoon tended to have thicker shells than those sampled outside the lagoon $(P=0.052)$ (Fig. 5) (Table 2). In addition, shell thickness correlated positively with shell size (Fig. 5, Table 2). Furthermore, our Mantel tests showed that there was no significant correlation between shell morphology and geographic distance (Table 3), and this suggests that morphological differences do not reflect spatial autocorrelation. In summary, our results suggest that 
the $S$. quadrata shells are the same size both inside and outside of the lagoon, but the shells of $S$. quadrata sampled inside the lagoon are thicker than those of $S$. quadrata sampled outside the lagoon.

The different environmental pressures inside and outside of the lagoon potentially led to the observed morphological differences in S. quadrata shells. Predators represent one such environmental pressure. Different shell morphologies result in several defense mechanisms against predators. For example, in freshwater snails in the genus Physa, globular shells interfere with predation from fish and elongated shells from crayfish (Dewitt et al. 2000). Furthermore, the narrowness of the shell's aperture and its thickness affect shell-breaking predators (Appleton \& Palmer 1988, Trussell 2006, Konuma \& Chiba 2007). In recent years, there was a huge outbreak of crayfish in Kahoku Lagoon (Kahokugata Lake Institute 2013). Furthermore, cyprinid fishes also occur in Kahoku Lagoon (Kahokugata Lake Institute 2013), and these fish feed on freshwater mollusks (Imamura \& Hashitani 1957, Correia et al. 2005, Moriyama 2007). Thus, crayfish and cyprinid fishes, which can be predators of freshwater mollusks, may have caused differences in shell morphology between the sampling sites located inside and outside of Kahoku Lagoon.

Furthermore, water physical environments are another factor that may underlie the morphological differences in S. quadrata shells. Some morphological features of the shell function may reduce the stress caused by wave and/ or water current effects (Way et al. 1993, Kihira 1996, Urabe 1998, Le Pennec et al. 2017). There are waves inside the lagoon (Shirai \& Kawahara 2005), and there are many environments in which water flows in one direction outside the lagoon. Due to the large differences in these physical properties, morphological differences in S. quadrata shells may occur.

Additionally, as freshwater mollusks produce shells using calcium ions in the water, the concentration of these ions in the environment affects shell thickness (Marin et al. 1996, Rundle et al. 2004). However, this effect can be ignored in the present study because there were no differences in the calcium ion concentrations inside and outside of the lagoon. Alternatively, fast-growing snails develop thin, globular shells that accommodate more body mass than their thicker, more elongated counterparts (Kemp $\&$ Bertness 1984). If the S. quadrata in the lagoon grow slowly, they are likely to have thick, elongated shells. This mechanism may be able to explain the morphological differences observed in this study.

Our results show that $S$. quadrata sampled within the lagoon had elongated cylindrical shells. The $S$. quadrata population within the lagoon has been established in the last 60 years because of the history of the lagoon. The origin of the lagoon population is not clear; however, it is highly possible that the lagoon population was introduced from the surrounding area, because freshwater habi- tats within and outside the lagoon are connected by water channels (Fig. 2). In addition, even if the S. quadrata population within the lagoon and the $S$. quadrata population outside the lagoon have different origins, it is likely that the two populations have a certain gene flow due to these water channels. The dispersal ability of freshwater mollusks including Viviparidae in small and connected habitats (Ribi 1986, Ribi \& Arter 1986, Statzner et al. 2008, Kappes \& Haase 2012) may also facilitate this. Furthermore, our Mantel tests showed that there was no significant correlation between shell morphology and geographic distance (Table 3), and this suggests that morphological differences do not reflect the origin and/or primitive history of immigration of each population. Considering these factors, the morphological differences between $S$. quadrata sampled within the lagoon and outside the lagoon are likely to have developed after the desalination of the lagoon. That is to say, the observed changes may be a consequence of either phenotypic plasticity or rapid morphological evolution. To distinguish between these two mechanisms underlying morphological change, further studies using highresolution genetic markers are required. Nevertheless, the present findings suggest that morphological variation occurred in S. quadrata as a result of their habitat differences between flowing water and the lagoon. A similar qualitative relationship between shell morphology and habitat has also been observed in $S$. quadrata sampled inside and outside of Lake Biwa (Hirano et al. 2015). This relationship may be general in S. quadrata, although further indepth studies are needed. Thus, the consistent relationship between morphological variation and habitat suggests that the environment of the lake affects the morphology of viviparid mollusks. Furthermore, the presumed flexibility in shell morphology of freshwater mollusks may emphasize the importance of considering habitat environment in species assessment, identification, and studies that examine shell morphology.

\section{Acknowledgements}

We thank H. Takahashi, M. Nagasaka and N. Kawahara in Kahokugata Lake Institute for their advice on the survey sites. We also thank T. Hirano, B. Ye, and D. Yamazaki for their valuable comments on the manuscript. This study was supported by a grant for the encouragement of scientists from the Kahokugata Lake Institute (Kahokugata Research Promotion Support 2017).

\section{References}

Appleton RD, Palmer AR (1988) Water-borne stimuli released by predatory crabs and damaged prey induce more predatorresistant shells in a marine gastropod. Evolution 85: 4387-4391.

Bates D, Maechler M, Bolker B, Walker S, Christensen RHB, Singmann H, Dai B, Scheipl F, Grothendieck G, Green P, Fox J (2019) lme4: Linear mixed-effects models using ‘Eigen' and 
S4. version 1.1-21. Available at: https://CRAN.R-project.org/ package $=$ exactRankTests (accessed on 1 July 2019).

Becker M, Zielske S, Haase M (2016) Conflict of mitochondrial phylogeny and morphology based classification in a pair of freshwater gastropods (Caenogastropoda, Truncatelloidea, Tateidae) from New Caledonia. Zookeys 603: 17-32.

Cazenave KR, Zanatta DT (2016) Environmental drivers of shell shape in a freshwater gastropod from small and large lakes. Freshw Sci 35: 948-957.

Correia AM, Bandeira N, Anastácio PM (2005) Predatorprey interactions of Procambarus clarkii with aquatic macroinvertebrates in single and multiple prey systems. Acta Oecologica 28: 337-343.

Covain R, Fisch-Muller S, Oliveira C, Mol JH, Montoya-Burgos JI, Dray S (2016) Molecular phylogeny of the highly diversified catfish subfamily Loricariinae (Siluriformes, Loricariidae) reveals incongruences with morphological classification. Mol Phylogenet Evol 94: 492-517.

Deiner K, Bik HM, Mächler E, Seymour M, Lacoursiére-Roussel A, Altermatt F, Creer S, Bista I, Lodge DM, Vere dN, Pfrender ME, Bernatchez L (2017) Environmental DNA metabarcoding: Transforming how we survey animal and plant communities. Mol Ecol 26: 5872-5895.

Dewitt TJ, Robinson BW, Wilson DS (2000) Functional diversity among predators of a freshwater snail imposes an adaptive trade-off for shell morphology. Evol Ecol Res 2: 129-148.

Doyle D, Gammell MP, Nash R (2018) Morphometric methods for the analysis and classification of gastropods: a comparison using Littorina littorea. J Mollus Stud 84: 190-197.

Du L, Yang J, Rintelen VT, Chen X, Aldridge D (2013) Molecular phylogenetic evidence that the Chinese viviparid genus Margarya (Gastropoda: Viviparidae) is polyphyletic. Chinese Sci Bull 58: 2154-2162.

Dunithan A, Jacquemin S, Pyron M (2012) Morphology of Elimia livescens (mollusca: Pleuroceridae) in Indiana, U.S.A. covaries with environmental variation. Am Malacol Bull 30: 127-133.

Garnett ST, Christidis L (2017) Taxonomy anarchy hampers conservation. Nature 546: 25-27.

Glaubrecht M, Köhler F (2004) Radiating in a river: systematics, molecular genetics and morphological differentiation of viviparous freshwater gastropods endemic to the Kaek River, central Thailand (Cerithioidea, Pachychilidae). Biol J Linn Soc 82: $275-311$.

Havermans C, Nagy ZT, Sonet G, De Broyer C, Martin P (2010) Incongruence between molecular phylogeny and morphological classification in amphipod crustaceans: a case study of Antarctic lysianassoids. Mol Phylogenet Evol 55: 202-209.

Hirano T, Saito T, Chiba S (2015) Phylogeny of freshwater viviparid snails in Japan. J Mollus Stud 81: 435-441.

Hirano T, Saito T, Tsunamoto Y, Koseki J, Ye B, Do VT, Miura O, Suyama Y, Chiba S (2019) Enigmatic incongruence between mtDNA and nDNA revealed by multi-locus phylogenomic analyses in freshwater snails. Sci Rep 9: 6223.

Hollander J, Collyer ML, Adams DC, Johannesson K (2006) Phenotypic plasticity in two marine snails: constraints superseding life history. J Evol Biol 19: 1861-1872.

Hothorn T, Hornik K (2019) exactRankTests: exact distributions for rank and permutation tests. version 0.8-30. Available at: https://CRAN.R-project.org/package=exactRankTests (accessed on 1 July 2019).

Hoverman JT, Relyea RA (2009) Survival trade-offs associated with inducible defences in snails: the roles of multiple predators and developmental plasticity. Funct Ecol 23: 1179-1188.

Irestedt M, Fjeldså J, Ericson PG (2004) Phylogenetic relationships of woodcreepers (Aves: Dendrocolaptinae)-incongruence between molecular and morphological data. J Avian Biol 35: $280-288$.

Imamura T, Hashitani S (1957) On the food habits of four fishes in Marsh Hinuma. Bull Fac Lib Arts Ibaraki Univ Nat Sci 7: $45-56$

Iwata H, Ukai Y (2006) SHAPE Ver 1.3 A software package for quantitative evaluation of biological shapes based on elliptic Fourier descriptors. J Hered 93: 384-385.

Jackson ISC, Claybourn TM (2018) Morphometric analysis of inter and intraspecific variation in the Cambrian helcionelloid mollusc Mackinnonia. Palaeontology 61: 761-773.

Kahokugata Lake Institute (2013) Red Data Book in Kahokugata Lake. Hashimoto-Kakubundou Co., Ltd. (in Japanese)

Kappes H, Haase P (2012) Slow, but steady: dispersal of freshwater molluscs. Aquat Sci 74: 1-14.

Kawahara N, Takahashi H (2001) Kogan saisei wo mezashite zouseishita biotope-ike no keika [Progress of biotope ponds aimed at lakeshore regeneration]. Kahahoku Lake Sci 4: 1-16. (in Japanese)

Kemp P, Bertness MD (1984) Snail shape and growth rates: evidence for plastic shell allometry in Littorina littorea. Proc Natl Acad Sci 81: 811-813.

Kihira H (1996) Nakaseko-kawanina [Semisulcospira nakasekoae]. In: Nihon no Kisyouna Yasei Suisann Seibutsu ni Kannsuru Kiso Shiryou (III) [Basic Data on Rare Wildlife in Japan (III)] (ed Fisheries Agency). Japan Fisheries Resource Conservation Association, Tokyo, pp. 13-16. (in Japanese)

Köhler F (2016) Rampant taxonomic incongruence in a mitochondrial phylogeny of Semisulcospira freshwater snails from Japan (Cerithioidea: Semisulcospiridae). J Mollus Stud 82: 268-281.

Köhler F, Glaubrecht M (2006) A systematic revision of the Southeast Asian freshwater gastropod Brotia (Cerithioidea: Pachychilidae). Malacologia 48: 159-251.

Konuma J, Chiba S (2007) Trade-offs between force and fit: extreme morphologies associated with feeding behavior in carabid beetles. Am Nat 170: 90-100.

Kurozumi T. 2013 Shimoenakashima iseki kara erareta kairui itai [Fossil molluscs occurred from Shimonakae Ruins]. In: Shimonokae Kamihiokimeotogi Iseki Kumamoto Ken Bunkazai Chousa [Shimonakae and Kamihiokimeotogi Ruins, The Research Report of Archaeological Surveys in Kumamoto] (ed Kumamoto Education Committee). Kumamoto Prefectural Board of Education, Kumamoto, pp. 83-92. (in Japanese)

Le Pennec G, Butlin RK, Jonsson PR, Larsson AI, Lindborg J, Bergström E, Westram AM, Johannesson K (2017) Adaptation to dislodgement risk on waveswept rocky shores in the snail Littorina saxatilis. PLoS One 12: 1-15.

Lee T, Hong HC, Kim JJ, Ó Foighil D (2007) Phylogenetic and taxonomic incongruence involving nuclear and mitochondrial 
markers in Korean populations of the freshwater snail genus Semisulcospira (Cerithioidea: Pleuroceridae). Mol Phylogenet Evol 43: 386-397.

Lenat DR, Resh VH (2006) Taxonomy and stream ecology the benefits of genus and species level identifications. J North Am Benthol Soc 20: 287-298.

Nomura T, Takahashi H (2006) Kahokugata chi-iki no riku tansui san kairui-sou [Land and freshwater molluscan fauna of Kahoku Lagoon area]. Kahokugata Lake Sci 9: 7-22.

Mace GM (2004) The role of taxonomy in species conservation. Philos Trans R Soc B Biol Sci 359: 711-719.

Marin F, Smith M, Isa Y, Muyzer G, Westbroek P, Isat Y, Muyzert G, Westbroek P (1996) Skeletal matrices, muci, and the origin of invertebrate calcification. Proc Natl Acad Sci USA 93: $1554-1559$.

Masuda O, Uchiyama R (2004) Himetanishi [Sinotaia quadrata histrica]. In: Nihon San Tansui Kairui Zukan 2, Kisui Iki wo Fukumu Zenkoku no Kaisan Kairui [Freshwater Mollusks of Japan 2, Freshwater Mollusks of Japan Including Brackish Water Species]. Pisces, Tokyo, pp. 54-55. (in Japanese)

Miura O, Köhler F, Lee T, Li J, Foighil Dó (2013) Rare, divergent Korean Semisulcospira spp. mitochondrial haplotypes have Japanese sister lineages. J Mollus Stud 79: 86-89.

Moriyama H (2007) Basic knowledge about ecosystem conservation (1) Historical aspects of the paddy-field ecosystems. J Agric Eng Soc, Japan 75: 331-336.

Oksanen J, Blanchet FG, Friendly M, Kindt R, Legendre P, McGlinn D, Minchin PR, O'Hara RB, Simpson GL, Solymos P, Stevens MHH, Szoecs E, Wagner H (2019) Ordination methods, diversity analysis and other functions for community and vegetation ecologists. version 2.5-5. Available at: https://CRAN.Rproject.org/package $=$ vegan (accessed on 1 July 2019).

Patterson C, Williams DM, Humphries CJ (1993) Congruence between molecular and morphological phylogenies. Annu Rev Ecol Evol Syst 24: 153-188.

Pfenninger M, Cordellier M, Streit B (2006) Comparing the efficacy of morphologic and DNA-based taxonomy in the freshwater gastropod genus Radix (Basommatophora, Pulmonata). BMC Evol Biol 6: 100.

Preston SJ, Roberts D (2007) Variation in shell morphology of Calliostoma zizyphinum (Gastropoda: Trochidae). J Mollus Stud 73: 101-104.

Ribi G (1986) Within-lake dispersal of the prosobranch snails, Viviparus ater and Potamopyrgus jenkinsi. Oecologia 69: 6063.

RiBi G, Arter H (1986) Sex related difference of movement speed in the freshwater snail Viviparus ater. J Mollus Stud 52: 91-96.

R Development Core Team (2005) R: A Language and Environment for Statistical Computing. Vienna, Austria: R foundation for statistical computing. ISBN 3-900051-07-0, Available at: http://www.R-project.org (accessed on 1 July 2019)

Rundle SD, Spicer JI, Coleman RA, Vosper J, Soane J (2004) Environmental calcium modifies induced defences in snails. Proc R Soc B Biol Sci 271: 67-70.

San JM, Doorenweerd C, Leblanc L, Barr N, Geib S, Rubinoff D (2018) Incongruence between molecules and morphology: a seven-gene phylogeny of Dacini fruit flies paves the way for reclassification (Diptera: Tephritidae). Mol Phyloghet Evol 121: $139-149$.

Schneider CA, Rasband WS, Eliceiri KW (2012) NIH Image to ImageJ: 25 years of image analysis. Nat Methods 9: 671.

Saito T, Prozorova L, Sitnikova T, Surenkhorloo P, Hirano T, Morii Y, Chiba S (2018a) Molecular phylogeny of glacial relict species: a case of freshwater Valvatidae molluscs (Mollusca: Gastropoda) in North and East Asia. Hydrobiologia 818: $105-118$.

Saito T, Van TD, Prozorova L, Hirano T, Fukuda H, Chiba S (2018b) Endangered freshwater limpets in Japan are actually alien invasive species. Conserv Genet 19: 947-958.

Shirai N, Kawahara N (2005) Kahokugata no engantai no syokusei omoni kanahusarigawa kakou-iki syu-hen ni tsuite [Vegetation of the coastal zone in Kahoku lagoon, about the vicinity of the estuary of kanakusari river]. Kahoku Lake Sci 8: 23-30. (in Japanese)

Statzner B, Bonada N, Dolédec S (2008) Biological attributes discriminating invasive from native European stream macroinvertebrates. Biol. Invasions. 10: 517-530.

Trussell GC (2006) Phenotypic plasticity in an intertidal snail: the role of a common crab predator. Evolution 50: 448.

Urabe M (1998) Contribution of genetic and environmental factors to shell shape variation in the lotic snail Semisulcospira reiniana (Prosobranchia: Pleuroceridae). Mollus Stud 64: 329_ 343.

Way CM, Burky AJ, Lee MT (1993) The relationship between shell morphology and microhabitat flow in the endemic Hawaiian stream limpet (Hihiwai), Neritina granosa (Prosobranchia: Neritidae). Pac Sci 47: 263-275.

Williams ST, Hall A, Kuklinski P (2012) Unraveling cryptic diversity in the Indo-West Pacific gastropod genus Lunella (Turbinidae) using elliptic fourier analysis. Am Malacol Bull 30: 189-206. 